\title{
Dipyridamole reversal using theophylline during aminophylline shortage
}

Our cardiac positron emission tomography (PET) center traditionally administers intravenous aminophylline to reverse unpleasant side-effects and infrequent ischemia from dipyridamole. However, in December 2010 aminophylline experienced a drug shortage. While the Food and Drug Administration announced that the shortage had been resolved in February 2011, ${ }^{1}$ the American Society of Health-System Pharmacists posted another shortage in July $2011 .^{2}$ Therefore, we would like to summarize briefly our experience using theophylline as an alternative.

Aminophylline is a salt containing approximately $80 \%$ theophylline by weight. ${ }^{3}$ Therefore, typical doses of 75 to $125 \mathrm{mg}$ of aminophylline require only 60 to $100 \mathrm{mg}$ of theophylline. However, theophylline for intravenous administration is much more dilute than aminophylline. For example, suppliers offer $10 \mathrm{~mL}$ vials containing $250 \mathrm{mg}$ of aminophylline $(25 \mathrm{mg} / \mathrm{mL})$, but $500 \mathrm{~mL}$ bags containing $400 \mathrm{mg}$ of theophylline $(0.8 \mathrm{mg} / \mathrm{mL})$. To avoid a large volume infusion in most patients, we usually administered $50 \mathrm{mg}$ of theophylline (roughly filling a $60 \mathrm{~mL}$ syringe), corresponding to approximately $60 \mathrm{mg}$ of aminophylline. Injection of theophylline by hand required around 1 minute. A second injection was performed in rare cases for refractory symptoms.

Between January and June 2011, we administered theophylline to 154 patients as described above. Only 11 (7\%) required a second injection. Side-effects or frank ischemia from dipyridamole were successfully treated in all cases. No manifestations of theophylline toxicity, such as dysrhythmia, nausea, vomiting, tremors, or seizures, were noted. Literature review of theophylline in humans to reverse dipyridamole discovered four studies with a combined total of 61 patients, all published between 1984 and 1994 from Sweden. ${ }^{4-7}$ Therefore, our largest series provides modern evidence in cardiac PET that theophylline can replace aminophylline during aminophylline shortages.

Nils P. Johnson, $M D, M S$

K. Lance Gould, MD

Weatherhead PET Center for Preventing

and Reversing Atherosclerosis,

Division of Cardiology,

Department of Medicine,

University of Texas Medical School and Memorial Hermann Hospital,

Houston, TX

K.Lance.Gould@uth.tmc.edu

\section{References}

1. Food and Drug Administration (FDA), Resolved Drug Shortages. http://www.fda.gov/Drugs/DrugSafety/DrugShortages/ucm050793. htm. Accessed August 1, 2011.

2. American Society of Health-System Pharmacists, Drug Shortage Product Bulletin for Aminophylline. http://www.ashp.org/Drug Shortages/Current/Bulletin.aspx?id=705. Accessed August 1, 2011.

3. Hospira Inc., Aminophylline package insert. http://products.hospira. com/assets/pdfs/EN-2301.pdf. Accessed August 1, 2011.

4. Sollevi A, Ostergren J, Fagrell B, Hjemdahl P. Theophylline antagonizes cardiovascular responses to dipyridamole in man without affecting increases in plasma adenosine. Acta Physiol Scand 1984;121:165-71.

5. Linde B, Sollevi A. Effects of dipyridamole and theophylline on reactive hyperaemia in subcutaneous adipose tissue in humans. Clin Physiol 1987;7:319-27.

6. Edlund A, Sollevi A, Wennmalm A. The role of adenosine and prostacyclin in coronary flow regulation in healthy man. Acta Physiol Scand 1989;135:39-46.

7. Rask LP, Karp KH, Teien DE. Hemodynamic changes during dipyridamole stress in patients with aortic stenosis. J Heart Valve Dis 1994;3:510-5.

doi:10.1007/s12350-011-9445-1 